\title{
Pendampingan Kegiatan Pengolahan Limbah Kotoran Sapi Menjadi Pupuk Organik Guna Mendukung Usaha Pertanian dan Peternakan di Pedesaan
}

\author{
Riky Andyawan*, Laila Nur Fadhila, Rina Mardiyana, Syafarina Nadhilah \\ Universitas Muhammadiyah Purworejo \\ Jl. KHA. Dahlan 3 Purworejo, 54111 Jawa Tengah Indonesia \\ *email: rikyandy@gmail.com
}

\begin{abstract}
Abstrak - Usaha peternakan sapi di desa Arjowinangun tergolong banyak, namun selama ini belum ada upaya dari masyarakat untuk mengolah limbah padat kotoran sapi menjadi pupuk organik. Limbah kotoran sapi yang dihasilkan seharusnya tidak lagi menjadi beban biaya usaha tetapi menjadi hasil yang memiliki nilai ekonomis tinggi. Tujuan dari program ini yaitu yaitu peternak dapat lebih memanfaatkan kotoran sapi agar dapat meningkatkan nilai jual kotoran tersebut sehingga dapat menambah penghasil. Bagi para petani agar memanfaatkan pupuk organik tersebut agar tanah menjadi lebih subur dan kualitas serta kuantitas hasil pertanian meningkat. Metode yang digunakan pada kegiatan ini yaitu tahap persiapan, tahap pelaksanaan dan tahap pelaporan. Tahap persiapan meliputi persiapan tim, materi, dan sosialisasi program. Tahap pelaksanaan meliputi dua kegiatan yaitu pemberian materi atau sosialisasi dan praktek dari limbah kotoran sapi. Tahap pelaporan yaitu penyusunan laporan akhir berdasarkan hasil sosialisasi dan pelatihan. Hasil yang dicapai alam kegiatan ini adalah sadarnya masyarakat akan pentingnya penggunaan pupuk organik bagi tanaman serta manfaatnya dalam menjaga mineral tanah agar tetap subur, warga mengerti mengenai dampak buruk penggunaan jangka panjang dari pupuk kimia anorganik. Satu hal yang paling penting adalah masyarakat mengetahui cara membuat pupuk dari limbah kotoran sapi. Penyuluhan ini juga membuat warga antusias dan tertarik untuk mulai menggunakan pupuk kandang seperti pupuk kotoran sapi untuk menyuburkan tumbuhan dan tanah pada areal pertanian mereka.
\end{abstract}

Kata kunci: Kotoran sapi, Pupuk organik, Pertanian, Peternakan

\section{Assistance for Processing of Cow Manure Waste into Organic Fertilizer to Support Agriculture and Animal Husbandry in Rural Areas}

\begin{abstract}
There are many cattle farming businesses in Arjowinangun village, but so far there has been no effort from the community to process solid waste cow dung into organic fertilizer. The resulting cow dung waste should no longer be a burden on business costs but a product that has high economic value. The objective of this program is that farmers can better utilize cow dung in order to increase the selling value of the dung so that it can increase production. For farmers to use organic fertilizers so that the soil becomes more fertile and the quality and quantity of agricultural produce increases. The method used in this activity is the preparation stage, implementation stage and reporting stage. The preparation stage includes team preparation, materials, and program socialization. The implementation stage includes two activities, namely providing material or socialization and practice of cow dung waste. The reporting stage is the preparation of a final report based on the results of socialization and training. The results achieved by this activity were the community's awareness of the importance of using organic fertilizers for plants and its benefits in maintaining soil minerals in order to remain fertile, the residents understood the bad effects of long-term use of inorganic chemical fertilizers. One of the most important things is that people know how to make fertilizer from cow dung waste. This counseling also made residents enthusiastic and interested in starting to use manure such as cow manure to fertilize plants and soil in their agricultural areas.
\end{abstract}

Keyword: Cow manure, organic fertilizers, agriculture, animal husbandry 


\section{PENDAHULUAN}

Sektor peternakan di Indonesia sampai hari ini masih menjadi salah satu sumber ketahanan pangan yang sangat strategis. Namun, kondisi di lapnagn belum terkelola secara profesional tetapi sebagian besar merupakan usaha peternakan rakyat berskala kecil yang berada di pedesaan dan masih menggunakan teknologi sederhana atau tradisional. Hewan ternak mengeluarkan kotoran dalam jumlah banyak sebagai hasil limbah. Limbah didefinisikan sebagai sisa atau buangan dari suatu usaha dan atau kegiatan manusia (PP No. 18/1999 Jo. 85/199).

Pada ternak sapi, jumlah kotoran yang dikeluarkan 12\% dari berat tubuh atau 10-15 ton per ekor per tahun. Apabila kotoran tersebut tidak diolah dengan baik akan menimbulkan dampak bagi lingkungan berupa pencemaran udara, air dan tanah, menjadi sumber penyakit, dapat memacu peningkatan gas metan dan juga gangguan pada estetika dan kenyamanan karena kotoran ternak mengandung NH3, NH, dan senyawa lainnya (Sukamta, dkk., 2017).

Pengembangan sektor usaha peternakan sekarang ini diarahkan tidak hanya terkait dengan pemenuhan pangan, namun juga mulai dikembangkan pada pemanfaatan limbah kotoran sapi (teletong) menjadi pupuk organik. Daur ulang limbah ternak mempunyai peranan penting dalam mencegah terjadinya pencemaran lingkungan. Limbah ternak sebagai hasil akhir dari usaha peternakan memiliki potensi untuk diolah menjadi pupuk organik seperti kompos yang dapat dimanfaatkan untuk meningkatkan daya dukung lingkungan, meningkatkan produksi tanaman, meningkatkan pendapatan petani dan mengurangi dampak pencemaran terhadap lingkungan (Okoroafor, dkk., 2013). Pemberian berbagai jenis kompos limbah padat kotoran ternak dapat memperbaiki sifat fisik, kimia dan biologi tanah dan meningkatkan daya dukungnya lingkungan sehingga pemanfaatannya sebagai lahan pertanian akan dapat meningkatkan produksi tanaman.

Saat ini, di Desa Arjowinangun terdapat kurang lebih 55 ekor sapi yang dikelola oleh kelompok maupun individu. Namun, selama ini belum ada upaya dari masyarakat untuk mengolah limbah padat kotoran sapi menjadi pupuk organik. Limbah kotoran sapi yang dihasilkan seharusnya tidak lagi menjadi beban biaya usaha tetapi menjadi hasil yang memiliki nilai ekonomis tinggi. Kotoran yang diolah menjadi pupuk akan meningkatkan kualitas serta nilai jual yang tinggi. Pemanfaatan feses menjadi pupuk sangat baik bagi kesuburan tanah dan menyediakan unsur hara yang dibutuhkn tanaman. Selain dapat meningkatkan usaha peternakan, maka pengolahan feses menjadi pupuk organik dapat meningkatkan usaha pertanian karena pupuk merupakan kebutuhan pokok para petani untuk mengelola tanamannya di lahan pertanian (sawah maupun ladang). Penggunaan pupuk organik dapat meningkatkan kesuburan tanah sehingga akan meningkatkan kuantitas dan kualitas hasil pertanian.

Kegiatan ini merupakan serangkian kegiatan kuliah kerja nyata Universitas Muhammadiyah Purworejo yang mengangkat program kerja unggulan yaitu di Desa Arjowinangun, Kecamatan Buluspesantren, Kabupaten Kebumen.

\section{METODE PELAKSANAAN}

Sasaran kegiatan program pemanfaatan limbah kotoran sapi menjadi pupuk organik yaitu masyarakat yang beternak sapi dan petani yang ada di Desa Arjowinangun. Metode yang digunakan dalam program pemanfaatan limbah kotoran sapi menjadi pupuk organik melalui beberapa tahapan, yaitu: 


\section{Tahap Persiapan}

Tahap ini terdiri dari tahap pembentukan tim kerja, survei awal, dan perencanaan pelaksanaan kegiatan serta penyiapan materi pelatihan pembuatan pupuk organik dari limbah kotoran sapi. Sebelum pelaksanaan kegiatan, tim terlebih dahulu mensosialisasikan program pupuk organik kepada warga. Sosialisasi berfungsi untuk menggali lebih dalam mengenai permasalahan yang dialami masyarakat dan solusi yang dibutuhkan. Dengan begitu, diharapkan program pemanfaatan limbah ini dapat memberikan luaran yang sesuai dengan keinginan dan kebutuhan masyarakat.

2. Tahap Pelaksanaan

Tahap pelaksanaan meliputi beberapa kegiatan antara lain: sosialisasi dan penyampaian materi pupuk organik dari limbah kotoran sapi, praktek pembuatan pupuk organik dari limbah kotoran sapi.

3. Tahap Pelaporan

Pada tahap ini dilakukan pembuatan laporan akhir. Laporan akhir dibuat berdasarkan hasil sosialisasi dan pelatihan dari limbah kotoran sapi.

\section{HASIL DAN PEMBAHASAN}

Kegiatan diawali dengan sosialisasi dan pemaparan materi tentang pengelolaan limbah baik itu dari kotoran hewan maupun tumbuhan untuk dijadikan pupuk organik. Kegiatan ini mendatangkan narasumber dari Dinas Pertanian Kecamatan Buluspesantren yaitu Bapak Ruslan. Kegiatan yang bertajuk pelatihan pembuatan pupuk organik ini dilaksanakan di balai desa yang diikuti oleh puluha warga, mahasiswa yang melaksanakan $\mathrm{KKN}$, serta perangkat desa. Adapun dokumentasi kegaitan disajikan pada Gambar 1.

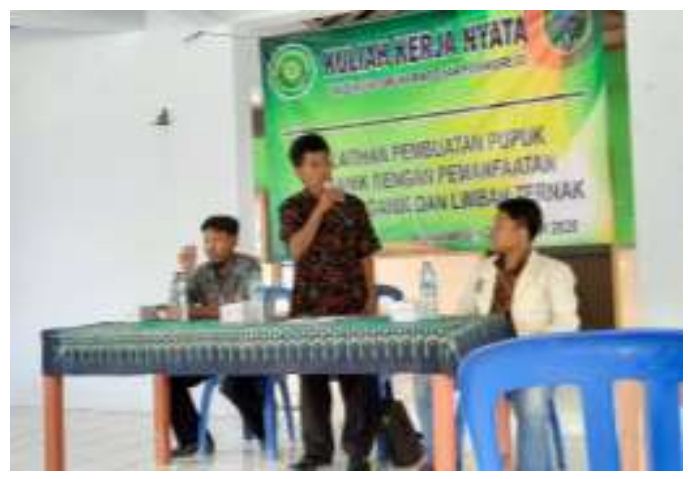

Gambar 1. Pemaparan materi pembuatan pupuk organik

Kegiatan pelatihan dilaksanakan secara berkelompok. Peserta dibagi menajdi beberapa kelompok dan dalam bentuk praktik secara langsung membuat pupuk organik yang berbahan dasar limbah kotoran sapi. Praktik pembuatan pupuk dipimpin langsung oleh Bapak Ruslan dan mendapat antusias dari peserta kegiatan. 

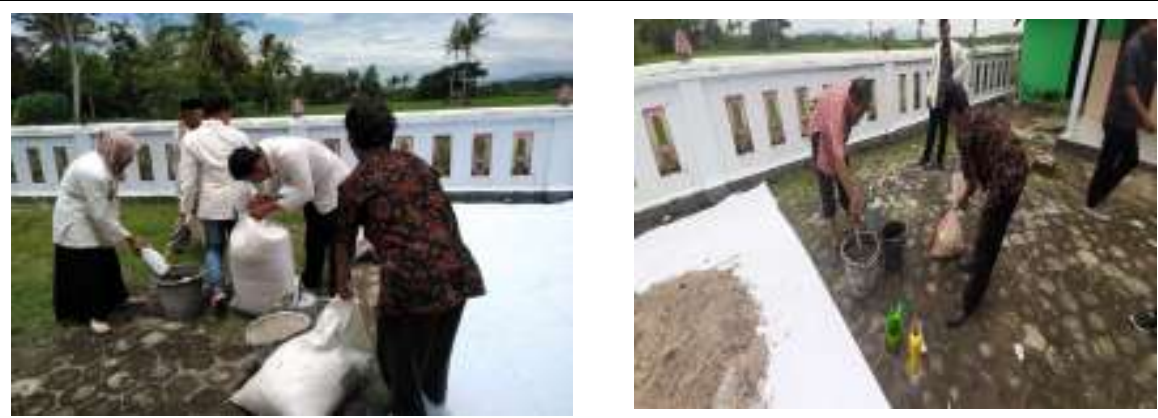

Gambar 2. Pengolahan limbah kotoran sapi

Gambar 2 menyajikan peserta pelatihan yang didampingi oleh mahasiswa KKN melakukan praktik langsung pembautan pupuk organik yang didampingi oleh narasumber. Mekanismenya melalui pencampuran berbagai bahan utama pembuatan pupuk, yang diolah sedemikian rupa sehingga menjadi pupuk organik siap pakai. Adapun alat dan bahan serta langkal-langkah pembuatan pupuk organik yang berbahan dasar limbah kotoran sapi (teletong):

\section{Alat dan bahan}

Alat:

Bahan:

1. Terpal untuk damparan dan

1. 6 kandi (3 kwintal) kotoran sapi penutup

2. $1 / 4$ gula pasir

2. Cangkul atau sekop

3. Bekatul $10 \mathrm{~kg}$

3. Gembor

4. Sekam mentah 2 karung

4. Ember plastik

5. Dolomit 1 karung

5. Gayung

6. EM4 1 botol

7. Air secukupnya

\section{Langkah-langkah atau Proses Pembuatan Pupuk :}

1. Untuk dapat menampung kotoran sapi sebanyak 3 ton maka ukuran yang dibutuhkan adalah dua meter kali satu meter dengan kedalaman dua meter. Bila memungkinkan pembuatan silo dapat juga dilakukan dengan mempergunakan gorong-gorong berpenampang 1 meter dan disusun sebanyak tidak lebih dari 3 buah. Sesuai dengan ukuran gorong- gorong yang ada di pasaran maka, dua buah gorong-gorong ditempatkan di bawah permukaan tanah (sedalam 90 $\mathrm{cm}$ ) dan sebuahnya lagi dapat ditumpuk di atas permukaan tanah (setinggi $100 \mathrm{~cm}$ ).

2. Dengan ukuran silo dapat menampung tiga ton kotoran sapi. Kotoran sapi yang tersedia selanjutnya diaduk agar tercampur secara merata antara feses, urine dan sisa pakan. Bila telah homogen maka kotoran sapi dapat dimasukan ke dalam silo secara baik agar cukup padat sampai hampir penuh.

3. Selanjutnya dapat ditutup dengan menggunakan tanah galian lubang yang ada setinggi lebih kurang $30 \mathrm{~cm}$. Timbunan tersebut selanjutnya dibiarkan untuk suatu satuan waktu tertentu, misalnya 3 bulan (Mathius, 1994), namun pada umumnya disesuaikan dengan waktu penggunaannya, yakni disesuaikan dengan musim tanam.

4. Setelah melewati waktu yang diinginkan diharapkan kotoran yang telah melewati proses perombakan/dekomposisi, dapat menjadi kompos yang diharapkan dan siap dibongkar. 
Kompos tersebut selanjutnya dapat dipergunakan secara langsung ke lahan pertanian atau pun dapat dianginkan/dikeringkan di bawah sinar matahari.

5. Hasil pengeringan tersebut selanjutnya dihancurkan agar tidak menggumpal/padat dan dapat disaring dengan ayakan yang sesuai dengan ukuran-ukuran yang diinginkan. Untuk tujuan sebagai pupuk tanaman hias maka hasil ayakannya harus cukup kecil (2-3 mm).

Hasil yang dicapai dalam kegiatan ini adalah sadarnya masyarakat akan pentingnya penggunaan pupuk organik bagi tanaman serta manfaatnya dalam menjaga mineral tanah agar tetap subur sehingga dalam jangka panjang dapat tetap memberikan hasil panen yang melimpah. Melalui kegiatan ini warga juga menjadi lebih mengerti mengenai dampak buruk penggunaan jangka panjang dari pupuk kimia an organik. Hal ini didukung oleh kajian Roidah, I. S. (2013) terkait pengaruh pupuk kimia terhadap tanaman Satu hal yang paling penting adalah masyarakat mengetahui cara membuat pupuk organik secara mandri menggunaan bahan dasar yang ada di sekitar meraka, dalam hal ini kotoran sapi menjadi fokus utama. Hal tersebut sejalan dengan kegiatan serupa yang dilaksanakan oleh Wicaksono, I. A., \& Nurhadi, R. (2017) terkait bagaimana optimalisasi pertanian menggunakan bahan organik. Penyuluhan ini juga membuat warga antusias dan tertarik untuk mulai menggunakan pupuk kandang seperti pupuk kotoran sapi untuk menyuburkan tumbuhan dan tanah pada areal pertanian mereka.

\section{KESIMPULAN}

Pupuk organik atau yang berasal dari bahan organik merupakan sumber nitrogen tanah yang utama dimana peranannya cukup besar terhadap perbaikan sifat kimia dan biologi tanah serta lingkungan. Kegiatan ini meningkatkan kesadaran masyarakat akan pentingnya penggunaan pupuk organik bagi tanaman serta manfaatnya dalam menjaga mineral tanah agar tetap subur sehingga dalam jangka panjang dapat tetap memberikan hasil panen yang melimpah. Setelah mengetahui manfaat penggunaan pupuk organik dan cara mengolahnya masyarakat desa Arjowinangun yang banyak berprofesi sebagai peternak dan petani diharapkan dapat mengurangi penggunaan pestisida atau pupuk kimia sehingga mengurangi resiko keracunan zat tersebut dan mengurangi dampak kerusakan tanah jangka panjang. Penggunaan pupuk organik buatan sendiri jugadianjurkan guna mengkemat biaya operasional sehingga petani lebih banyak memperoleh laba bersih dari hasil pertanian mereka.

\section{Ucapan Terima Kasih}

Ucapan terima kasih kepada segenap warga desa Arjowinangun, kecamatan Buluspesantren kabupaten kebumen yang telah berkenan menerima dan melaksanakan kegiatan. Terima kasih untuk sahabat-sahabat yang telah banyak membantu kegiatan, antara lain Annisa Wirananda, Setyo Adi Putro, Uli Hamdiyah Faidah, Nourma Yufianti, Qori Nanda Avazul Fikar, Yuli Indah Sari, Maytha Maharani, Ika Rachmawati, Entin Febrinia, Dwi Apriliyani, Meliana Wulandari, Indra Laksana Putra, Ressa Ramadhan Kurniawan, Adi Subekti

\section{DAFTAR PUSTAKA}


Okoroafor, I.B, Okelola, E.O, Edeh, O. Nemehute, V.C., Onu, C.N., Nwaneri, T.C. and Chinaka, G.I. (2013). Effect of Organic Manure on the Growth and Yield Performance of Maize and Poultry Manure Application in the Guinea Savanna Agro-ecological Zone in Nigeria. J. Biol. Agric. Healthc 2(2):44-56.

Roidah, I. S. (2013). Manfaat penggunaan pupuk organik untuk kesuburan tanah. Jurnal Bonorowo, 1(1), 30-43.

Sukamta., Muhammad Abdus Shomad, dan Andika Wisnujati. (2017). Pengelolaan Limbah Ternak Sapi Menjadi Pupuk Organik Komersial di Dusun Kalipucang, Bangunjiwo, Bantul, Yogyakarta. Jurnal Berdikari 5 (1): 1-10.

Wicaksono, I. A., \& Nurhadi, R. (2017). Pengembangan Pertanian Organik Bidang Kemandirian Pupuk dan Pemasaran Desa Cokroyasan, Ngombol, Purworejo. Surya Abdimas, 1(1), 14-18. 